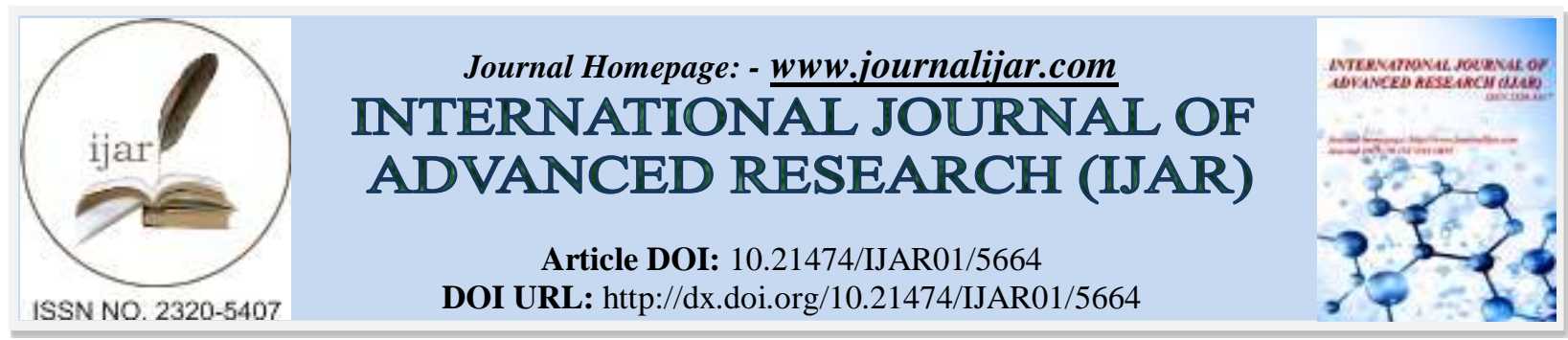

RESEARCH ARTICLE

\title{
GENOTYPIC EVALUATION, HETEROTIC POTENTIAL AND COMBINING ABILITY OF YIELD AND FRUIT QUALITY ATTRIBUTING TRAITS IN TOMATO (Solanum lycopersicum L.)
}

\section{Sadia Sabrina Alam ${ }^{1}$, Nasrin Akter Ivy², M. A. Khaleque Mian ${ }^{2}$, M. Mizanur Rahman ${ }^{3}$ and Faridul Alam ${ }^{4}$}

1. Plant Breeding Division, Bangladesh Agricultural Research Institute, Gazipur 1701, Bangladesh.

2. Department of Genetics and Plant Breeding, Bangabandhu Sheikh Mujibur Rahman Agricultural University, Salna, Gazipur 1706, Bangladesh.

3. Department of Horticulture, Bangabandhu Sheikh Mujibur Rahman Agricultural University, Salna, Gazipur 1706, Bangladesh.

4. Soil Science Division, Bangladesh Agricultural Research Institute, Gazipur 1701, Bangladesh.

\section{Manuscript Info}

Manuscript History

Received: 19 August 2017

Final Accepted: 21 September 2017

Published: October 2017

Key words:-

Combining Ability, Gene Action, Heterosis, Diallel Analysis, Yield and Tomato.

\begin{abstract}
A study was conducted to know the heterosis and combining ability effects for yield and fruit quality contributing traits in a $6 \times 6$ diallel analysis excluding reciprocals by using 6 parents namely Deepam, Nidhi, Tyrex, Tyqueen, Tyking and Sonali in randomized complete block design with three replications during the winter season October, 2010 to March 2011. All observed traits were governed by both additive and non-additive type of gene actions, though the additive gene action was prominent which revealed the polygene involvement in inheritance. The parent Nidhi was an excellent general combiner for individual fruit weight and yield per plant and Deepam for fruits per plant. Parent Tyrex was the best general combiner for fruits per cluster, fruit diameter and total soluble solids $\left({ }^{\circ}\right.$ brix $)$. The cross combination Deepam $\times$ Sonali was the best specific combiner for yield per plant while NidhixTyking for fruit length and individual fruit weight, Tyrex $\times$ Sonali for fruit width and fruits per plant. The cross combination Deepam $\times$ Sonali showed the highest significant heterobeltosis for individual fruit weight and fruit yield per plant and Tyrex $\times$ Sonali for fruits per plant.
\end{abstract}

Copy Right, IJAR, 2017,. All rights reserved.

\section{Introduction:-}

Tomato is a kind of vegetable which has been cultivated worldwide including Bangladesh due to wider adaptability, high yielding potential, diverse use, nutritional value and good taste. It tops the list among the canned vegetables as well as used directly as raw vegetables in sandwiches and salad. Tomato in large quantities is used in several processed items like pasta, soup, pickles, puree, sauces, ketchup, jelly, juices and many other ways. As a matter of fact, the number of ways it can be used to improve the flavor and character of other foods is endless. Tomato contains vitamin A, C, lycopene, flavonoid and other minerals which are beneficial for human health (Bhowmik et al., 2012 and Akhtar et al., 2013). Many developing countries like Bangladesh benefited from the revolution in cereal production in the past could not able to reduce malnutrition and poverty. Vegetables production can help farmers to generate income which eventually alleviate poverty as well as include more nutrition in their diet to make it balance diet. At present 30,608 hectares area is under tomato cultivation both in winter and summer (BBS, 
2015).To boost up production potentiality of tomato in the country exploitation of hybrid technology might be an alternative method.

Combining ability is one of the powerful tools used in the breeding program for testing the performance of lines in hybrid combinations, exploit heterosis or to accumulate fixable genes and also for characterizing the nature and magnitude of gene action. It helps the breeder to design effective breeding plan for future up gradation of the existing materials. This information associated with combining ability is very useful in determining the combination of parents for the best progeny with high potential productivity and other selected novel traits. This analysis is often used for different crops, such as tomato (Farzane et al., 2012; Saleem et al., 2013; Saputra et al., 2014 and Habu et al., 2016), chilli (Hasanuzzaman et al., 2012,), potato (Haydar et al., 2009), eggplant (Nalini et al., 2011), cucumber (Kumar et al., 2016), bread wheat (Ali et al., 2014) and corn (Iriany et al., 2011 and Alam et al., 2017).

Besides combining ability, value of heterosis can also be used as one important consideration for selecting parent genotype and novel hybrid (Aisyah et al., 2016). As a consequence, the main goal of this research was to gather information of GCA, SCA and heterosis value in tested tomato genotypes.

\section{Materials and methods:-}

The experiment was conducted at the experimental field, Department of Genetics and Plant Breeding, Bangabandhu Sheikh Mujibur Rahman Agricultural University (BSMRAU), Salna, Gazipur. Soil of BSMRAU farm belongs to Salna series of shallow red brown terrace soil type (Brammer, 1971; Shaheed, 1984) with silty clay in surface and silty clay loam in sub surface region The experimental site was situated in the sub- tropical climate zone, characterized by heavy rainfall during the months from May to September and scanty rainfall in the rest of the year. Seeds of $15 \mathrm{~F}_{1}$ s from a diallel cross without reciprocals were developed during the winter season, October 2009 to March 2010. These $15 \mathrm{~F}_{1} \mathrm{~s}$ and their 6 parents namely Deepam, Nidhi, Tyrex, Tyqueen, Tyking and Sonali were grown in same experimental field following Randomized Complete Block Design with 3 replications. The unit plot size was $4.8 \times 1 \mathrm{~m}$ accommodating 24 plants in a plot having row to row and plant to plant spacing of $60 \mathrm{~cm} \times 40 \mathrm{~cm}$. The unit plot and blocks were separated by $50 \mathrm{~cm}$ and $1 \mathrm{~m}$ respectively. Treatments were randomly allotted in each block. The seedlings were transplanted to the field after emergence of 4-5 true leaves (around 4 weeks old). The observations were recorded on randomly selected five plants from parents and $F_{1} s$ in each replication. Three yield contributing traits viz. yield per plant (kg), fruits per plant (no.) and fruits per cluster (no.); four fruit quality attributing traits viz. fruit length $(\mathrm{cm})$, fruit width $(\mathrm{cm})$, fruit weight $(\mathrm{g})$ and total soluble solids $\left({ }^{\circ}\right.$ brix) were observed. Total soluble solids (TSS) reading was observed with help of refractometer in ${ }^{\circ}$ brix. The mean performances of all characters were analyzed using Crop Stat software. General combining ability (GCA) and specific combining ability (SCA) were estimated following Model I, Method II of Griffing (1956). For estimation of heterosis in each trait, the mean values of the $15 \mathrm{~F}_{1}$ 's have been compared with better parent (BP) for heterobeltiosis (Table 5).

$$
\text { Heterobeltosis }(\%)=\frac{\mathrm{F}_{1}-\mathrm{BP}}{\mathrm{BP}} \times 100
$$

Where, $F_{1}=$ mean performance of cross, BP = mean performance of better parent. Significance of heterosis is tested with the help of standard error using ' $t$ ' test.

\section{Result and discussion:-}

The analysis of variance exposed the existence of significant variation among genotypes for all traits related to yield and fruit quality associated traits. Table 1 shows mean squares from the analysis of variance for all the traits. Presence of significant differences among genotypes for all the traits asserted to combining ability analysis (Singh and Chaudhary, 1979).

Table 1:- Analysis of variance for yield and fruit quality contributing traits in tomato

\begin{tabular}{|l|l|l|l|l|l|l|l|l|}
\hline & \multicolumn{7}{|c|}{ Mean squares } \\
\hline $\begin{array}{l}\text { Source of } \\
\text { Variation }\end{array}$ & $\mathrm{df}$ & $\begin{array}{l}\text { YPP } \\
(\mathrm{Kg})\end{array}$ & $\begin{array}{l}\text { FPP } \\
\text { (no.) }\end{array}$ & $\begin{array}{l}\text { FPC } \\
(\text { no. })\end{array}$ & $\begin{array}{l}\text { FL } \\
(\mathrm{cm})\end{array}$ & $\begin{array}{l}\text { FD } \\
(\mathrm{g})\end{array}$ & $\begin{array}{l}\text { FW } \\
(\mathrm{g})\end{array}$ & $\begin{array}{l}\text { TSS } \\
\left({ }^{\circ} \text { brix }\right)\end{array}$ \\
\hline Replication & 2 & 0.001 & 5.25 & 0.036 & 0.033 & 0.05 & 7.97 & 0.031 \\
\hline
\end{tabular}




\begin{tabular}{|l|l|l|l|l|l|l|l|l|}
\hline & \multicolumn{7}{|c|}{ Mean squares } \\
\hline $\begin{array}{l}\text { Source of } \\
\text { Variation }\end{array}$ & df & $\begin{array}{l}\text { YPP } \\
(\mathrm{Kg})\end{array}$ & $\begin{array}{l}\text { FPP } \\
(\text { no. })\end{array}$ & $\begin{array}{l}\text { FPC } \\
(\text { no. })\end{array}$ & $\begin{array}{l}\text { FL } \\
(\mathrm{cm})\end{array}$ & $\begin{array}{l}\text { FD } \\
(\mathrm{g})\end{array}$ & $\begin{array}{l}\text { FW } \\
(\mathrm{g})\end{array}$ & $\begin{array}{l}\text { TSS } \\
\left({ }^{\circ} \text { brix }\right)\end{array}$ \\
\hline Genotype & 20 & $1.16^{* *}$ & $217^{* *}$ & $2.48^{* *}$ & $0.424^{* *}$ & $0.379^{* *}$ & $3056^{* *}$ & $2.57^{* *}$ \\
\hline Error & 40 & 0.018 & 1.31 & 0.028 & 0.026 & 0.028 & 1.22 & 0.013 \\
\hline
\end{tabular}

*Significant at $5 \%$ level, $* *$ Significant at $1 \%$ level

YPP=Yield per plant, FPP= Fruits per plant, FPC=Fruits per cluster, FL=Fruit length, FD=Fruit diameter, FW=Fruit weight, TSS=Total soluble solids

Mean squares due to combining ability exhibited highly significant difference among the genotype due to both GCA and SCA for all the traits (Table 2) indicating that, both GCA and SCA effects played vital roles controlling those traits except fruit diameter for GCA. Both additive and non-additive gene action were involved in inheritance of all traits viz. yield per plant, number of fruits per plant, number of fruits per cluster, fruit length, fruit weight and total soluble solids where only fruit diameter may be influenced by non-additive gene effect. Hannan et al. (2007a), Hannan et al. (2007b) also found significant variation for both GCA and SCA for yield per plant, fruits per plant and total soluble solids ( ${ }^{\circ}$ brix) in tomato following $10 \times 10$ diallel evaluation excluding reciprocals. Muttappanavar et al. (2014) evaluated GCA and SCA in $7 \times 7$ half diallel mating design and reported similar type results for yield per plant, fruits per plant, fruits per cluster and fruit weight in cherry tomato which indicated the importance of both additive and non-additive gene action in the expression of traits. Gul (2011) evaluated highly significant GCA and SCA for characters fruit length, fruit diameter and fruit weight on $8 \times 8$ half diallel cross. The relative proportion of GCA variances to SCA variances for traits yield per plant, fruits per plant, fruits per cluster, fruit weight and total soluble solids were $1.59,3.32,15.3,1.22$ and 2.73 respectively (Table 2) pointed out the predominance of the additive gene effects for these traits.

Table 2:- Mean squares from combining ability analysis and genetic ratio for yield and fruit quality contributing traits in diallel cross of tomato

\begin{tabular}{|l|c|l|l|l|l|l|l|l|}
\hline $\begin{array}{l}\text { Source of } \\
\text { Variation }\end{array}$ & df & $\begin{array}{l}\text { YPP } \\
(\mathrm{Kg})\end{array}$ & $\begin{array}{l}\text { FPP } \\
(\text { no. })\end{array}$ & $\begin{array}{l}\text { FPC } \\
(\text { no. })\end{array}$ & $\begin{array}{l}\text { FL } \\
(\mathrm{cm})\end{array}$ & $\begin{array}{l}\text { FD } \\
(\mathrm{g})\end{array}$ & $\begin{array}{l}\text { FW } \\
(\mathrm{g})\end{array}$ & $\begin{array}{l}\text { TSS } \\
\left({ }^{\circ} \text { brix }\right)\end{array}$ \\
\hline GCA & 5 & $0.54^{* *}$ & $152^{* *}$ & $2.76^{* *}$ & $0.13^{* *}$ & 0.02 & $1179^{* *}$ & $1.64^{* *}$ \\
\hline SCA & 15 & $0.34^{* *}$ & $45.9^{* *}$ & $0.18^{* *}$ & $0.15^{* *}$ & $0.16^{* *}$ & $965^{* *}$ & $0.60^{* *}$ \\
\hline Error & 40 & 0.01 & 0.44 & 0.01 & 0.01 & 0.01 & 0.41 & 0.01 \\
\hline GCA/ SCA & - & 1.59 & 3.32 & 15.3 & 0.866 & 0.125 & 1.22 & 2.73 \\
\hline
\end{tabular}

* Significant at $5 \%$ level, ** Significant at $1 \%$ level

YPP=Yield per plant, FPP= Fruits per plant, FPC=Fruits per cluster, FL=Fruit length, FD=Fruit diameter, FW=Fruit weight, TSS=Total soluble solids

However, those genetic ratios for traits fruit length and fruit diameter were 0.87 and 0.13 consequently indicated the importance of non-additive gene action more than that of additive type gene action in inheritance of traits. Ahmed et al. (2009), Aisyah et al. (2016) and Habu et al. (2017) found similar results that additive gene action was more prominent to control the observed traits viz. yield per plant, fruits per plant, fruits per cluster, fruit weight and total soluble solids ( ${ }^{\circ}$ brix) whereas Saleem et al. (2013) and Habu et al. (2017) reported resemble predominance of nonadditive gene action for fruit length and fruit diameter respectively. Oppositely, Gaikwad et al. (2009) and Saleem et al. (2013) observed more influence of non-additive gene action than additive on yield per plant, fruits per plant as well as fruit weight traits and Habu et al. (2017) traced that for fruits per plant and yield per plant as the populations were different.

General combining ability refers to the average performance of a line in a series of cross combinations and it is attributable to additive (fixable) gene action, thus GCA value supports in selection of superior parents for breeding programs. A wide range of variability of GCA effects was observed among the parents in this study. GCA effects for seven yield and fruit quality contributing traits are presented in table 3. Significant and positive GCA effects were considered as good general combiners for all the traits. The parent Nidhi showed the highest significant positive GCA value $(4.61 * *)$ followed by Tyqueen $\left(3.81^{* *}\right)$ and Sonali $\left(0.317^{* *}\right)$ for yield per plant but in contrast the highest significant negative GCA effect was obtained by parent Tyking $\left(-4.39^{* *}\right)$ followed by parent Deepam ($\left.2.55^{* *}\right)$ and Tyrex $(-1.80 * *)$. Therefore the parents Nidhi, Tyqueen and Sonali were the best general combiners can be used in crosses for the improvement of fruits yield per plant. Both parents Deepam and Tyrex displayed 
significant positive values for the trait number of fruits per plant and number of fruits per cluster where Deepam $(4.91 * *)$ and Tyrex $(0.717 * *)$ was the best general combiner for number of fruits per plant and number of fruits per cluster respectively. Among six parents, Deepam and Nidhi exhibited significant positive value for both fruit length and diameter traits whereas Tyqueen $(5.27 * *)$ secured the highest significant value for fruit length and Tyrex $(0.869 * *)$ for fruit diameter (Table 3$)$.

Table 3:- Estimation of general combining ability (GCA) effects for yield and fruit quality attributing traits in tomato

\begin{tabular}{|c|c|c|c|c|c|c|c|}
\hline Parents & $\begin{array}{l}\text { YPP } \\
(\mathrm{Kg})\end{array}$ & $\begin{array}{l}\text { FPP } \\
\text { (no.) }\end{array}$ & $\begin{array}{l}\text { FPC } \\
\text { (no.) }\end{array}$ & $\begin{array}{l}\text { FL } \\
(\mathrm{cm})\end{array}$ & $\begin{array}{l}\text { FD } \\
(\mathrm{g})\end{array}$ & $\begin{array}{l}\text { FW } \\
(\mathrm{g})\end{array}$ & $\begin{array}{l}\text { TSS } \\
\text { ( }{ }^{\circ} \text { brix) }\end{array}$ \\
\hline Deepam & $-2.55 * *$ & $4.91 * *$ & $0.579 * *$ & $0.726 * *$ & $0.253 * *$ & $0.522 *$ & $0.579 * *$ \\
\hline Nidhi & $4.61 * *$ & $-2.96 * *$ & $0.10 * *$ & $2.98 * *$ & $0.174 * *$ & $1.88^{* *}$ & $0.10 * *$ \\
\hline Tyrex & $-1.80 * *$ & $4.24 * *$ & $0.717 * *$ & $-2.62 * *$ & $0.869 * *$ & $-1.24 * *$ & $0.717 * *$ \\
\hline Tyqueen & $3.81 * *$ & -0.358 & $-0.26 * *$ & $5.27 * *$ & 0.036 & 0.164 & $-0.258 * *$ \\
\hline Tyking & $-4.39 * *$ & $-6.60 * *$ & $-0.85 * *$ & $-4.02 * *$ & $-0.79 * *$ & $-1.67 * *$ & $-0.846 * *$ \\
\hline Sonali & $0.317 * *$ & $0.767 * *$ & $-0.29 * *$ & $-2.33 * *$ & $-0.54 * *$ & $0.347 *$ & $-0.292 * *$ \\
\hline SE(gi) & 0.026 & 0.213 & 0.031 & 0.030 & 0.031 & 0.206 & 0.022 \\
\hline $\mathrm{CD}_{(5 \%)}$ & 0.053 & 0.430 & 0.063 & 0.061 & 0.063 & 0.416 & 0.044 \\
\hline $\mathrm{CD}_{(1 \%)}$ & 0.070 & 0.576 & 0.084 & 0.081 & 0.084 & 0.557 & 0.059 \\
\hline
\end{tabular}

* Significant at $5 \%$ level, ** Significant at $1 \%$ level

$\mathrm{YPP}=$ Yield per plant, $\mathrm{FPP}=$ Fruits per plant, $\mathrm{FPC}=$ Fruits per cluster, $\mathrm{FL}=$ Fruit length, $\mathrm{FD}=$ Fruit diameter, $\mathrm{FW}=$ Fruit weight, TSS=Total soluble solids

The highest significant positive value $(1.88 * *)$ was analyzed in Nidhi followed by Deepam $(0.522 *)$ and Sonali $\left(0.347^{*}\right)$ for the trait individual fruit weight. Parent Tyrex showed the highest significant positive value $\left(0.717^{* *}\right)$ for TSS ( ${ }^{\circ}$ brix) followed by Deepam $(0.579 * *)$ and Nidhi $\left(0.10^{* *}\right)$ whereas the highest significant negative GCA effect was observed in parent Tyking $(-0.846 * *)$ followed by parent Sonali $(-0.292 * *)$ and Tyqueen $(-0.258 * *)$. Hence parents Tyrex, Deepam and Nidhi were the best general combiner to improve the qualitative character like TSS value. Gaikwad et al. (2009) found similar significant positive gca effect for yield contributing characters viz; fruit yield per plant and number of fruits per plant as well as for fruit quality attributing traits viz.; individual fruit weight and total soluble solids ( ${ }^{\circ}$ brix). On the other hand, Saleem et al. (2013) and Habu et al. (2016) examined that kind of significant positive gca for traits fruit yield per plant, number of fruits per plant, number of fruits per cluster, individual fruit weight, fruit length and fruit diameter.

The SCA effects specify the role of non-additive gene action in the expression of the traits. It indicates specific combining ability leading to the highest performance of some specific cross combinations. Thus it is related to a particular cross. High SCA effects may arise not only in crosses involving high combiners but also in those involving low combiners. The SCA effects of $15 \mathrm{~F}_{1}$ crosses for seven traits are presented in Table 4 . Among $15 \mathrm{~F}_{1} \mathrm{~s}$, 8 cross combinations showed highly significant positive SCA effects where the highest significant positive SCA effects were observed in the cross Deepam $\times$ Sonali $(1.23 * *)$ followed by Nidhi $\times$ Tyking $(0.854 * *)$ and Tyrex $\times$ Sonali $\left(0.495^{*}\right)$ which were the best specific combiner for increasing yield per plant. Nine, six, six, seven, nine and seven cross combinations were analyzed as highly significant and exhibited positive SCA effects for the traits fruits per plant, fruits per cluster, fruit length, fruit diameter, fruit weight and total soluble solids ( ${ }^{\circ}$ brix) respectively. The highest significant positive SCA effect was exhibited by the cross Tyrex $\times$ Sonali $(8.29 * *)$ followed by NidhixTyqueen $(5.98 * *)$ and Deepam $\times$ Sonali $\left(5.75^{* *}\right)$ for the trait number of fruits per plant whereas similar highest significant positive SCA effect was found in the cross NidhixTyrex $\left(0.698^{* *}\right)$ followed by Tyqueen $\times$ Tyking $\left(0.485^{* *}\right)$ and Nidhi $\times$ Sonali $\left(0.373^{* *}\right)$ for number of fruits per cluster $($ Table 3$)$. So these crosses were the best specific combiners for increasing fruits number per plant and fruits number per cluster respectively. The highest significant positive SCA estimated in the cross NidhixTyking $(0.551 * *)$ followed by Deepam $\times$ Tyqueen $(0.380 * *)$ and Tyrex $\times$ Sonali $\left(0.364^{* *}\right)$ for fruit length. In case of fruit diameter, the highest significant positive SCA effect was measured in the cross Tyrex $\times$ Sonali $(0.389 * *)$ followed by Nidhi $\times$ Tyking $(0.373 * *)$ and Deepam $\times$ Tyrex $\left(0.343^{* *}\right)$. The best specific combiner for increasing individual fruit weight was found in NidhixTyking (32.2**) cross combination followed by NidhixTyrex (31.9**) and Deepam $\times$ Tyqueen (18.3**). Among $15 \mathrm{~F}_{1} \mathrm{~s}, 7$ crosses showed highly significant positive SCA effects. The highest significant positive SCA effects were observed in the cross Nidhi×Sonali $(1.48 * *)$ followed by Tyrex×Tyking $(0.959 * *)$ and Deepam $\times$ Tyqueen $(0.771 * *)$ which were the 
best specific combiner for total soluble solids in fruits (Table 3). These results were resembled to Yadav et al. (2013), Saleem et al. (2013) and Muttappanavar et al. (2014).

Table 4:- Estimation of specific combining ability (SCA) effects of crosses for yield and fruit quality contributing traits in tomato

\begin{tabular}{|c|c|c|c|c|c|c|c|}
\hline Crosses & $\begin{array}{l}\text { YPP } \\
(\mathrm{Kg})\end{array}$ & $\begin{array}{l}\text { FPP } \\
\text { (no.) }\end{array}$ & $\begin{array}{l}\text { FPC } \\
\text { (no.) }\end{array}$ & $\begin{array}{l}\mathrm{FL} \\
(\mathrm{cm})\end{array}$ & $\begin{array}{l}\text { FD } \\
(\mathrm{g})\end{array}$ & $\begin{array}{l}\text { FW } \\
(\mathrm{g})\end{array}$ & $\begin{array}{l}\text { TSS } \\
\text { ( }{ }^{\circ} \text { brix) }\end{array}$ \\
\hline Deepam $\times$ Nidhi & $-0.301 * *$ & $4.25 * *$ & $-0.498 * *$ & 0.051 & -0.065 & $-36.2 * *$ & $-0.141 * *$ \\
\hline Deepam×Tyrex & $0.254 * *$ & $5.21 * *$ & $0.152 *$ & $0.314 * *$ & $0.343 * *$ & $11.1 * *$ & $-0.299 * *$ \\
\hline Deepam $\times$ Tyqueen & $0.304 * *$ & $-4.12 * *$ & 0.060 & $0.380 * *$ & $0.214 * *$ & $18.3 * *$ & $0.771 * *$ \\
\hline Deepam $\times$ Tyking & $-0.726 * *$ & $-12.1 * *$ & 0.081 & $-0.465 * *$ & $-0.698 * *$ & $14.2 * *$ & -0.079 \\
\hline Deepam $\times$ Sonali & $1.23 * *$ & $5.75^{* *}$ & $-0.440 * *$ & $-0.682 * *$ & $-0.257 * *$ & $9.19 * *$ & $-0.179 * *$ \\
\hline NidhixTyrex & 0.066 & $-10.0 * *$ & $0.698 * *$ & -0.036 & $-0.552 * *$ & $31.9 * *$ & $-0.837 * *$ \\
\hline NidhixTyqueen & $-0.684 * *$ & $5.98 * *$ & $-0.261 * *$ & -0.136 & $0.385 * *$ & $-73.6 * *$ & $-0.233 * *$ \\
\hline Nidhi $\times$ Tyking & $0.854 * *$ & $3.93 * *$ & 0.060 & $0.551 * *$ & $0.373 * *$ & $32.2 * *$ & $0.284 * *$ \\
\hline Nidhi $\times$ Sonali & $-0.292 * *$ & $-8.31 * *$ & $0.373 * *$ & $0.168 *$ & $-0.286 * *$ & $13.1 * *$ & $1.48 * *$ \\
\hline Tyrex $\times$ Tyqueen & $0.37 * *$ & $2.75 * *$ & $0.356 * *$ & 0.026 & $0.360 * *$ & $-8.55 * *$ & $0.576^{* *}$ \\
\hline Tyrex $\times$ Tyking & $0.174 * *$ & $5.53 * *$ & $-0.657 * *$ & $-0.520 * *$ & $-0.386^{* *}$ & $-5.74 * *$ & $0.959 * *$ \\
\hline Tyrex $\times$ Sonali & $0.495 * *$ & $8.29 * *$ & -0.044 & $0.364 * *$ & $0.389 * *$ & $7.48 * *$ & $0.259 * *$ \\
\hline Tyqueen $\times$ Tyking & $0.191 * *$ & $4.76 * *$ & $0.485 * *$ & $0.314 * *$ & $0.152 *$ & $-22.2 * *$ & $0.163 * *$ \\
\hline Tyqueen $\times$ Sonali & $-0.421 * *$ & 0.525 & $0.364 * *$ & $-0.236 * *$ & $-0.240 * *$ & $-17.6 * *$ & $-1.37 * *$ \\
\hline Tyking $\times$ Sonali & $-0.284 * *$ & $-5.39 * *$ & $-0.380 * *$ & $-0.215 * *$ & $-0.186^{*}$ & $10.6 * *$ & $-1.22 * *$ \\
\hline $\mathrm{SE}(\mathrm{Sij})$ & 0.058 & 0.483 & 0.071 & 0.069 & 0.071 & 0.467 & 0.049 \\
\hline $\mathrm{CD}_{(5 \%)}$ & 0.117 & 0.976 & 0.143 & 0.139 & 0.143 & 0.944 & 0.099 \\
\hline $\mathrm{CD}_{(1 \%)}$ & 0.157 & 1.31 & 0.192 & 0.187 & 0.192 & 1.263 & 0.132 \\
\hline
\end{tabular}

* Significant at 5\% level, ** Significant at $1 \%$ level

$\mathrm{YPP}=$ Yield per plant, $\mathrm{FPP}=$ Fruits per plant, $\mathrm{FPC}=$ Fruits per cluster, $\mathrm{FL}=$ Fruit length, $\mathrm{FD}=$ Fruit diameter, $\mathrm{FW}=\mathrm{Fruit}$ weight, TSS=Total soluble solids

The heterobeltosis expressed by the $F_{1}$ hybrids over the better parent for yield and fruit quality related traits are shown in Table 5. All the traits showed more or less significant heterosis in different crosses. Heterosis value $\geq 20$ seems justified to carry on breeding program for hybrid variety development in self- pollinated crops to improve yield and quality contributing traits. There is a potential to develop hybrids with better yield per plant and number of fruits per cluster in this research based on better parent heterosis. A number of cross combinations exhibited broad range of significant positive heterobeltosis for yield per plant ( $-51.2 \%$ to $59.1 \%)$, fruits per plant (-64.5\% to 36.0\%), fruits per cluster $(-29.1 \%$ to $8.68 \%)$, fruit length $(-19.8 \%$ to $8.78 \%)$, fruit diameter $(-16.7 \%$ to $9.94 \%)$, fruit weight ($72.5 \%$ to $19.6 \%)$ and total soluble solids $(-54.6 \%$ to $17.5 \%)$.

Table 5:- Percent heterosis over better parent for yield and fruit quality attributing traits in tomato

\begin{tabular}{|c|c|c|c|c|c|c|c|}
\hline Crosses & $\begin{array}{l}\text { YPP } \\
(\mathrm{Kg})\end{array}$ & $\begin{array}{l}\text { FPP } \\
\text { (no.) }\end{array}$ & $\begin{array}{l}\text { FPC } \\
\text { (no.) }\end{array}$ & $\begin{array}{l}\mathrm{FL} \\
(\mathrm{cm})\end{array}$ & $\begin{array}{l}\text { FD } \\
(\mathrm{g})\end{array}$ & $\begin{array}{l}\text { FW } \\
(\mathrm{g})\end{array}$ & $\begin{array}{l}\text { TSS } \\
\left({ }^{\circ} \text { brix }\right)\end{array}$ \\
\hline Deepam $\times$ Nidhi & $-22.7 * *$ & $-11.0 * *$ & $-18.4 * *$ & $-1.69 * *$ & $-3.75 * *$ & $-49.7 * *$ & $-3.70 * *$ \\
\hline Deepam×Tyrex & $10.6^{* *}$ & $10.8 * *$ & $-0.52 * *$ & $-1.69 * *$ & $0.60 * *$ & $12.8 * *$ & $-11.7 * *$ \\
\hline Deepam $\times$ Tyqueen & $4.76^{* *}$ & $-26.4 * *$ & $-15.6 * *$ & $2.26 * *$ & $0.60 * *$ & $-30.5 * *$ & $15.2 * *$ \\
\hline Deepam $\times$ Tyking & $-37.8 * *$ & $-64.5 * *$ & $-23.6 * *$ & $-12.4 * *$ & $-16.7 * *$ & $11.2 * *$ & $-4.04 * *$ \\
\hline Deepam $\times$ Sonali & $59.1 * *$ & $2.95 * *$ & $-23.2 * *$ & $-19.8 * *$ & $-8.70 * *$ & $19.6 * *$ & $-28.5 * *$ \\
\hline NidhixTyrex & $4.17 * *$ & $-38.2 * *$ & $4.87 * *$ & 0.00 & $-12.6 * *$ & $-4.13 * *$ & $-18.3 * *$ \\
\hline NidhixTyqueen & $-51.2 * *$ & $27.9 * *$ & $-7.74 * *$ & $1.21 * *$ & $4.92 * *$ & $-72.5 * *$ & $-14.8 * *$ \\
\hline Nidhi $\times$ Tyking & $47.9 * *$ & $-7.75 * *$ & $-12.5 * *$ & $8.78 * *$ & $1.61 * *$ & $15.9 * *$ & $5.56 * *$ \\
\hline Nidhi $\times$ Sonali & $-12.5 * *$ & $-41.1 * *$ & $2.98 * *$ & $2.42 * *$ & $-8.16 * *$ & $-8.86 * *$ & $5.29 * *$ \\
\hline Tyrex $\times$ Tyqueen & $-7.14 * *$ & $13.6 * *$ & $-5.47 * *$ & $0.68 * *$ & $9.94 * *$ & $-49.4 * *$ & $2.50 * *$ \\
\hline Tyrex $\times$ Tyking & $24.4 * *$ & $1.91 *$ & $-29.1 * *$ & $-14.5 * *$ & $-12.9 * *$ & $-15.6 * *$ & $17.5 * *$ \\
\hline Tyrex $\times$ Sonali & $47.9 * *$ & $36.0 * *$ & $-11.9 * *$ & $2.52 * *$ & $0.49 * *$ & $7.05 * *$ & $-12.2 * *$ \\
\hline Tyqueen $\times$ Tyking & $-16.7 * *$ & $16.2 * *$ & $8.68 * *$ & $2.97 * *$ & $-2.15 * *$ & $-43.0 * *$ & 0.00 \\
\hline
\end{tabular}




\begin{tabular}{|c|c|c|c|c|c|c|c|}
\hline Crosses & $\begin{array}{l}\text { YPP } \\
(\mathrm{Kg})\end{array}$ & $\begin{array}{l}\text { FPP } \\
\text { (no.) }\end{array}$ & $\begin{array}{l}\text { FPC } \\
\text { (no.) }\end{array}$ & $\begin{array}{l}\mathrm{FL} \\
(\mathrm{cm})\end{array}$ & $\begin{array}{l}\text { FD } \\
(\mathrm{g})\end{array}$ & $\begin{array}{l}\text { FW } \\
(\mathrm{g})\end{array}$ & $\begin{array}{l}\text { TSS } \\
\text { ('brix) }\end{array}$ \\
\hline Tyqueen $\times$ Sonali & $-32.1 * *$ & -0.59 & $6.51 * *$ & $-5.46 * *$ & $-7.62 * *$ & $-47.4 * *$ & $-54.6 * *$ \\
\hline Tyking $\times$ Sonali & $-6.25 * *$ & $-43.7 * *$ & $-19.8 * *$ & $-10.4 * *$ & $-8.60 * *$ & $11.3 * *$ & $-48.2 * *$ \\
\hline SE & 0.10 & 0.81 & 0.12 & 0.11 & 0.12 & 0.78 & 0.08 \\
\hline $\mathrm{CD}_{(5 \%)}$ & 0.20 & 1.64 & 0.24 & 0.22 & 0.24 & 1.58 & 0.16 \\
\hline $\mathrm{CD}_{(1 \%)}$ & 0.27 & 2.19 & -0.32 & 0.30 & 0.32 & 2.11 & 0.22 \\
\hline
\end{tabular}

* Significant at $5 \%$ level, ** Significant at $1 \%$ level

$\mathrm{YPP}=$ Yield per plant, $\mathrm{FPP}=$ Fruits per plant, $\mathrm{FPC}=$ Fruits per cluster, $\mathrm{FL}=$ Fruit length, $\mathrm{FD}=$ Fruit diameter, $\mathrm{FW}=$ Fruit weight, TSS=Total soluble solids

\section{Conclusion:-}

It may be concluded that additive gene action played a crucial role in the inheritance of traits viz., yield per plant, fruits per plant, fruits per cluster, fruit weight and total soluble solids. As a consequence, good general combiner parents concerning these traits can be used to develop superior hybrids. Nidhi and Deepam were the best general combiners for yield per plant and number of fruits per plant respectively, while both of them were good general combiner for the rest of five traits as well. Parent Tyrex was also a good parent to exploit and improve the traits fruits per cluster, fruit diameter and total soluble solids. The best cross combinations were Deepam $\times$ Sonali, Nidhi $\times$ Tyking and Tyrex $\times$ Sonali with higher significant SCA and more than $20 \%$ heterobeltosis for yield per plant. These crosses mostly involved low $\times$ high, high $\times$ low, low $\times$ high general combining parents and also performed as good specific combiners for other yield as well as fruit quality attributing traits.

\section{References:-}

1. Ahmad, S., Quamruzzaman, A.K.M. and Islam, M.R. (2011). Estimate of heterosis in tomato (Solanum lycopersicum L.). Bangladesh J. Agril. Res., 36(3): 521-527.

2. Aisyah, S.I., Wahyuni, S., Syukur, M. and Witono, J.R. (2016). The estimation of combining ability and heterosis effect for yield and yield components in tomato (Solanum lycopersicum mill.) at lowland. Eki. J. Crp. Breed. Gene., 2(1): 23-29.

3. Akhtar, S. and Hazra, P. (2013). Nature of gene action for fruit quality characters of tomato (Solanum lycopersicum L.). African J. of Biotech., 12(20): 2869-2875.

4. Alam, S.S., Amiruzzaman, M., Begum, S., Ahmed, A. and Alam, F. (2017). Gene action and combining ability assessment of field corn (Zea mays L.) using line $\times$ tester mating design. Int. J. Sustain. Crop Prod., 12(2):1116.

5. Ali, I.H. and Sulaiman, F.S. (2014). Analysis of combining ability, gene action and heterosis in a full diallel cross of bread wheat. Mesopotamia J. of Agric., 22 (1): 255-269.

6. BBS, (2016) Yearbook of Agricultural Statistics-2015. Statistics and informatics division (SID), 27:91-92.

7. Bhowmik, D., Kumar, K.P.S., Paswan, S. and Srivastava, S. (2012). Tomato-a natural medicine and its health benefits. J. of Pharma. and Phytochem., 1: 33-43.

8. Brammer, H. (1971). Soil resources, soil survey project, Bangladesh. AGL: SF/Pck. 6. Tech. Rep.3, 8p.

9. Farzane, A., Nemati, H., Arouiee, H., Kakhki, A.M. and Vahdati, N. (2012). The estimate of combining and heterosis for yield and yield components in tomato (Lycopersicon esculentum Mill.). J. Bio. Environ., 6: 129134.

10. Gaikwad, A.K., Cheema, D.S. and Garg, N. (2009). Diallel analysis involving heat-tolerant lines of tomato. Adv. Hort. Sci., 23(2): 87-93.

11. Griffing, B. (1956). Concept of general and specific combining ability in relation to dialle crossing systems. Aust. J. Biol. Sci., 9: 463-493.

12. Gul, R. (2011). Characterization and inheritance studies of desirable attributes in tomato. [disertasion]. Department of Plant Breeding and Genetics Faculty of Crop Production Sciences Khyber Pukhtunkhawa Agricultural University Peshawar, Pakistan.

13. Habu, S.H., Afolayan, S.O., Yaduma, J.J., Idris, B.A., Gwammaja, M.Y., Muhammad, S.M., Hudu, A.H., Idris, A.U., Ado, S.G., Yeye, M.Y., Usman, I.S., Usman, A. and Sagir, M. (2016). Combining ability and gene action for fruit yield and heat tolerance in tomato (Lycopersicon lycopersicum Mill.) under heat stress conditions. Int. J. Adv. Res., 4(7): 89-96. 
14. Hannan, M.M., Ahmed, M.B., Roy, U.K., Razvy, M.A., Haydar, A., Rahman, M.A., Islam, M.A. and Islam, R. (2007a). Heterosis, combining ability and genetics for brix\% days to first fruit ripening and yield in tomato (Lycopersicon esculentum Mill.). Middle East J. Sci. Res., 2:128-131.

15. Hannan, M.M., Biswas, M.M., Ahmed, M.B., Hossain, M. and Islam, R. (2007b). Combining ability analysis of yield and yield components in tomato (Solanum lycopersicum Mill). Turk. J. Bot., 31:559-563.

16. Hasanuzzaman, M., Hakim, M.A., Fersdous, J., Islam, M.M. and Rahman, L. (2012) .Combining ability and heritability analysis for yield and yield contributing characters in chilli (Capsicum annuum) landraces. Plt. Omi. J., 5(4): 337-344.

17. Haydar, A., Alam, M.K., Khokan, E.H., Ara, T. and Khalequzzaman, K.M. (2009). Combining ability and genetic variability studies in potato. J. Soil. Nat., 3(2): 01-03.

18. Iriany, R.N., Sujiprihati, S., Syukur, M., Koswara, J. and Yunus, M. (2011). Evaluation of combining ability and heterosis of five sweet corn lines (Zea mays var. saccharata) through diallel crossing. J. Agron. Indonesia, 39:103-111.

19. Kumar, P., Paliwal, A., Pant, S.C., Bahuguna, P. and Abrol, G. (2016). Heterosis studies in tomato (Lycopersicone esculentum Mill.) for yield and yield attributing traits for further implications in crop improvement. J. Bio. Innov., 5(6): 959-972.

20. Kumar, S., Kumar, R., Kumar, D., Gautam, N., Singh, N., Parkash, C., Dhiman, M.R. and Shukla, Y.R. (2017). Heterotic potential, potence ratio, combining ability and genetic control of yield and its contributing traits in cucumber (Cucumis sativus L.). Newzealand J. Cp. Hort. Sci., 45 (3): 175-190.

21. Muttappanavar, R.D., Sadashiva, A.T., Vijendrakumar, R.C., Roopa, B.N. and Vasantha, P.T. (2014). Combining ability analysis of growth, yield and quality traits in cherry tomato ( Solanum lycopersicum var. cersiforme). Mol. Plt. Breed., 5(4): 18-23.

22. Nalini, A.D., Patil, S.A. and Salimath, P.M (2011). Heterosis and combining ability analysis for productivity traits in brinjal (Solanum melongena L.). Karnataka J. Agric. Sci., 24:622-625.

23. Saputra, H.E., Syukur, M. and Aisyah, S.I. (2014). Combining ability and heritability estimation of tomato yield component in full diallel crosses. J. Agron. Indonesia, 42(3):203-209.

24. Shaheed, S.M. (1984). Soil of Bangladesh: general soil types. Soil Resources Development Institute (SRDI), Dhaka, Banglades, $3 \mathrm{p}$.

25. Singh, N.B., Wani, S.H., Haribhushan, A. and Nongthombam, R. (2012). Heterosis studies for yield and its components in tomato (Solanum lycopersicum L.) under valley conditions of manipur. Int. J. Plt. Res., 25(2): 257-265.

26. Singh, R.K. and Chaudhary, B.D. (1979). Biometrical methods in quantitative genetic analysis. Revised Edition. New Delhi: Kalyani.

27. Yadav, S.K., Singh, B.K., Baranwal, D.K. and Solankey, S.S. (2013). Genetic study of heterosis for yield and quality components in tomato (Solanum lycopersicum L.). Afr. J. Agric. Res., 8(44): 5585-5591. 